\title{
Firms' stock market flotation: Effects on inventory policy
}

\author{
Josep A. Tribó *,1 \\ Department of Business Administration, Carlos III University, 28903 Getafe, Spain
}

A R T I C L E I N F O

Available online 20 August 2008

JEL classification:

E22

G32

Keywords:

Inventory policy

Stock market flotation

Share issues

\begin{abstract}
A B S T R A C T
In this article, we argue that firms that are floated on the stock market are subject to close scrutiny by financial markets, which hinder them from implementing the type of empire-building overinvestment policies that may generate inventory accumulation (the signaling role of inventories). Also, listed firms have more resource availability to finance their investment projects and do not need to use inventories as a tool for dealing with their liquidity requirements (the liquidity role). Taking into account both these roles_signaling and liquidity_our main hypothesis is that after a firm is listed on the stock market, there is a decline in its inventory level as well as in its inventory variability, especially in those firms with larger liquidity needs (i.e., small firms and/or firms with financial difficulties). We further argue that the reductions in inventories will be larger for equity issues than for debt issues.

Using a sample of US manufacturing firms for the period 1994-2004, we find evidence that conforms to our theoretical predictions, suggesting a natural stabilizing mechanism that may smooth the economic cycle.
\end{abstract}

\section{Introduction}

There are different reasons that justify inventory investments. Focusing on the demand side, firms accumulate inventories as a buffer mechanism for attending unexpected demand and avoid stock outs. Under a supplyside perspective, inventories have different roles: They are indicators of operational mismanagement (Krautter, 1999), of future growth expectations (Lai, 2006), or credible signals that the firm is willing to compete fiercely in the future because it has enough slack to sell goods at a lower future price-signaling role-(Rotemberg and Saloner, 1989). But also, inventories allow companies to obtain liquidity in the short term-liquidity role(Guariglia, 2000). For example, firms can obtain funds in case of a liquidity shock like an increase in lending rates

\footnotetext{
* Tel.: +34 916249321; fax: +34916249608.

E-mail address: joatribo@emp.uc3m.es

${ }^{1}$ Departamento de Economía de la Empresa, Universidad Carlos III, C/ Madrid 126 (28903) Getafe, Spain.
}

by selling inventories at a price that is slightly lower than market value, for elastic-demand goods. In this way, inventories may be used as a substitute mechanism for financial instruments.

In this paper, we advance in this direction and we study the effect that firms' initial public offerings (IPOs) have on their inventory policies. To the best of our knowledge, this is an unexplored topic. The literature has mainly focused on the effect of an IPO in the overall firm's investment, ignoring the specificities of inventories. We believe that this is a relevant question to study, given the increased number of firms that float on the stock market, especially during expansive periods (Ritter and Welch, 2002). This, in turn, may affect inventory investment and, in the end, the overall economic cycle. Remarkably, inventories are responsible for up to $87 \%$ of the total peak-to-trough movement in GNP (Blinder and Maccini, 1991). The main conclusion of this paper is that there is a reduction in the inventory level after an IPO, suggesting a stabilizing mechanism that may smooth the overall economic cycle, since IPOs are pro-cyclical phenomena. 
Different effects are at work when financing issues and inventory investments are associated. First, inventories have a clear signaling role (Lai, 2006). According to different authors (Krautter, 1999; Lai, 2006), inventory accumulation is a signal of mismanagement. This means that those firms that are weakly monitored tend to accumulate more inventories. Tribó (2007) showed that the presence of specialists in monitoring, such as banks, reduces inventory levels as well as inventory variability. Under this view, a discount price should be observed in those firms that accumulate a large amount of inventories (Lai, 2006). Notably, financial markets are a powerful controlling mechanism and, thus, may preclude listed firms from accumulating a disproportionate amount of inventories and change them abruptly.

Second, after an IPO, there is a reduction in the cost of capital, which facilitates inventory investment (Lai, 2005). However, in the opposite direction, listed firms are less liquidity constrained and eventual liquidity shocks have lower effects on inventories (Guariglia, 2000), given that firms may use financial instruments to smooth these shocks. In this line, Kashyap et al. (1994) showed that liquidity measures are significant in explaining the inventory variation of firms that have difficulties in issuing bonds (without bond rating) but liquidity is not significant for explaining inventory variation for those firms that can issue bonds easily (with bond rating).

Finally, another strand of the literature connects inventories with overinvestment practices that are implemented when a firm has a specific ownership structure. Gomes and Novaes (2005) showed that in more diluted ownership structures (i.e., when there is a large amount of blockholders), overinvestment is less likely. This is so because the higher the number of shareholders, the more likely to have conflicting views on the type of investments to undertake. This prevents overinvestment actions like those that lead to intensive inventory accumulation. According to this view, ownership dilution, which is a common feature after an IPO, should hinder inventory accumulation.

Considering the foregoing arguments, we expect that, after an IPO, a firm should lower its inventory levels. This is the main claim of the paper and is consistent with the findings of Chen et al. (2005): a 2\% inventory reduction per year in the US between 1981 and 2000. Higher number of firms listed on the stock market during this period, ${ }^{2}$ jointly with the improvements in operational technology explaining the great moderation phenomenon in the US (Blanchard and Simon, 2000), will generate reductions in inventory level.

We address three extensions in this paper. First, we distinguish between final-good and raw-material inventories and hypothesize that inventory reduction in recently listed firms should be more pronounced for raw-material inventories. We argue that these are liquidtype inventories (less specific) and it is easier to sell them in the factor market. Hence, after an IPO, these more liquid inventories that a firm had relied on to raise liquidity will be the first ones to be substituted by financial instruments as liquidity-provider mechanisms. Second, we analyze different companies' characteristics and expect that firms with large liquidity needs or poorly monitored (i.e., small firms and/or with liquidity constraints) will benefit more from being listed on the stock market and their inventory reduction should be more pronounced. Last, looking beyond a firm's flotation, we study the effect of subsequent share issues by listed firms on inventory policy. We expect successive reductions in inventory levels, but on a smaller scale compared with the corresponding after the IPO. This logic also applies to debt issues, where we expect even lower effects. We test these theoretical contentions using a panel data sample of US manufacturing firms obtained from COMPUSTAT database for the period 1994-2004. Our results fully confirm our theory.

The remainder of the paper is organized as follows. Section 2 develops the theoretical underpinnings and presents the hypotheses to be tested. In Section 3, the empirical analysis is carried out. The paper concludes with some final remarks.

\section{Hypotheses to contrast}

We rely on the supply-side role of inventories as indicators, and marginally as liquidity providers for elastic-demand goods ${ }^{3}$ to build up our theoretical framework, which connects changes in ownership structure with inventory policy.

Concerning the signaling role of inventories, different issues should be taken into account. First, inventories may signal an operational mismanagement (Krautter, 1999; Lai, 2006). Second, they may be connected to good firm's futures sales perspectives (Lai, 2006). Last, firms may want to obtain a high issuing price by signaling themselves as a strong competitor. A way to achieve this is, for example, by accumulating a large amount of inventories in the period previous to the IPO. Hendel (1996) argued the importance of having inventories to compete in prices during downturns as a way to prevent a firm's financial distress. These three arguments suggest that, after the IPO, operational managers are likely to face pressures from financial markets to reduce inventory levels. First, there is an increase in the management control due to the close scrutiny from the investors that trade shares in financial markets, discouraging inventory overinvestment. Second, once a firm is listed on the stock market, market prices are the "natural" signaling mechanisms for future sales perspectives that wrap up all relevant information like that of inventory accumulation. Last, if a firm had overinvested in the period previous to an IPO as a way to signal itself as a strong competitor, it would have to

\footnotetext{
${ }^{2}$ A measure of this trend is that the share of the IPOs as percentage of the overall market value has increased from less than 3\% in 1990 to a peak of 13\% in 2000 (Rousseau, 2006).
}

\footnotetext{
${ }^{3}$ If demand is quite elastic, with a slight reduction in prices it is possible to increase substantial liquidity by selling inventories.
} 
credibly commit to this signal and sell products aggressively by disinvesting inventories. ${ }^{4}$ Then, according to these three foregoing arguments, a reduction in the inventory level is expected.

A second argument that justifies the reductions in inventory levels, together with their variability after an IPO, is connected to the increase in the number and the greater heterogeneity of shareholders once a firm is listed on the stock market. This makes agreements among shareholders over the investments to undertake more difficult to achieve (Gomes and Novaes, 2005). Heterogeneous shareholders' interests, when they are mutually exclusive, prevent overinvestment which, in turn, will lead to inventory reductions after an IPO. Additionally, this kind of mutual blockage over investment decisions also hinders significant variation in a firm's investment strategy. This will reduce inventory variability.

Finally, when we turn our attention to the possible liquidity role of inventories, we argue that for elasticdemand products that are not very specific (chemicals sector), inventories may act as a buffer mechanism for providing liquidity. For low-differentiation products, a firm can raise liquidity substantially by reducing slightly the price of the good sold which, in turn, will damage its competitors' customer base. This liquidity role of inventories is the basis of the Guariglia (2000) model, assuming that the cost of capital could be an increasing function of the shortterm debt to inventory ratio. That is, inventories are considered as easily-converted liquidity assets that reduce financing pressure and can be used to deal with financial obligations. Using such a model, the author derives an equation of inventories in terms of the previous period short-term debt-to-sales ratio and finds that this term is fully significant only for financially constrained firms. This confirms the liquidity role of inventories when there are no clear alternatives to liquidity provision like financial instruments or simply because they are market imperfections. Then, if a firm is listed on the stock market, financial instruments providing liquidity are easier to access and inventory accumulation will be less in demand to address liquidity issues like short-term financial obligations. This argument suggests a negative effect of an IPO in a firm's inventory accumulation. On the opposite side, firms may use financial assets - debt, equity, and different hybrid instruments - to finance its investment decisions like inventory accumulation. Calomiris et al. (1994) argued that firms may use commercial paper as a way to finance inventory investments during downturns. Also, Gertler and Gilchrist (1993) found that large firms (with access to financial markets) show substantial increases in inventories as well as short-term debt around cyclical peaks. This suggests that financial instruments may be used to finance real assets like inventories along the whole economic cycle. Summarizing, liquidity issues do not lead to a clear-cut conclusion on the effect of an IPO on inventory accumulation.

Concerning inventory variability, the existence of these different financing alternatives through financial markets

\footnotetext{
${ }^{4}$ Moreover, the underwriter of the IPO will stimulate this behavior in order to maintain its reputation.
}

makes inventory policy less dependent on liquidity shocks, reducing inventory variability. Along this line Kashyap et al. (1994) empirically showed and Hendel (1996) developed a theory predicting that inventories are more sensitive to liquidity shocks when a firm is credit constrained (i.e., it has a limited access to financial instruments). In conclusion, liquidity-financing issues suggest that the easy access to financing instruments after an IPO should be translated in a decrease in the inventory variability. Then, when we join signaling and liquidity arguments, we can state:

Hypothesis 1. Firms after an IPO, decrease their inventory level as well as their inventory variability.

Furthermore, we distinguish two important types of inventories, namely raw-goods inventories and finalgoods inventories. Raw-material inventories are more liquid inventories because they are less specific and can be easily cashed on input factor markets. This means that after an IPO, the liquidity needs of a firm, which are mainly satisfied through financing issues, will put less pressure on inventory accumulation, particularly on those that are more cashable (raw-material inventories). Then, we expect a steeper reduction in such a type of inventories after an IPO in comparison with final-good ones. Additionally, by focusing on signaling issues, a substantial accumulation of raw-good inventories is a more powerful signal that a firm is going to compete fiercely in the medium to long term. Then, the signaling role that share prices will play after an IPO will reduce the need to use inventories for signaling purposes whose role, as aforementioned, is more important in raw-material inventories. Hence, a steeper disinvestment in raw-material inventories is expected in comparison with final-good inventories. Consistent with this, Chen et al. (2005), who analyzed the components of the overall inventory investment for the US between 1981 and 2000, showed that raw materials declined about 3\% per year, whereas finishedgoods inventories did not decline at all. This is our second hypothesis to test:

Hypothesis 2. Inventory reductions after an IPO will be larger for raw-material inventories than for final-goods inventories.

Drawing from the previous arguments, we also expect a stronger effect on inventories after an IPO for those firms that have larger liquidity and/or signaling needs previous to the IPO. In this line, Kashyap et al. (1994), Hendel (1996), and Carpenter et al. (1994) showed that the inventory policy of firms with financing difficulties, like credit-constrained companies, are more sensitive to liquidity shocks. Then, an IPO as a positive liquidity shock should have more pronounced operational effects on these types of firms. ${ }^{5}$ Also, small firms, especially if they

\footnotetext{
${ }^{5}$ Also there is an informational argument that supports this contention. As mentioned before, Guariglia (2000) proves that debt-toinventory ratio is relevant to explain inventory policy in financially constrained firms. If a firm's short-term liabilities are important, then a firm has to maintain short-term liquidity assets like inventories, or risk being punished by investors. In this sense, inventories in the period
} 
are growing, bear large information asymmetries (adverse selection problems). Consequently, these firms are particularly eager to signal themselves as fierce competitors. They would use mechanisms such as inventory accumulation as signals if there are no signaling alternatives. These alternatives appear after an IPO in the form of more efficient mechanisms, like market prices, and inventories lose part of their informational content. Thus, we expect a steep decrease in the inventory level. Furthermore, in terms of control, small firms are expected to have less developed internal controlling mechanisms than larger firms. This means that the beneficial improvement in control due to the pressure from the financial markets, that prevents inventory overinvestment, will be larger for small firms in comparison with larger ones. This idea is captured in our third hypothesis:

Hypothesis 3. Inventory reductions after an IPO will be larger for small firms and firms with financing difficulties.

If we look at the effect of subsequent share issues after an IPO, we expect three consequences. First, the increase in a firm's liquidity and in the reduction of the cost of capital will be larger after an IPO in comparison with posterior share issues. ${ }^{6}$ Second, the control will not increase in these other issues because market institutions were already present since the initial offering. Third, the quality of the signal that a firm sends after the initial issue is more powerful than those of subsequent issues because the requirements that a firm has to satisfy are relatively more demanding for a non-listed firm previous to the first issue. These arguments suggest a steeper inventory reduction after an IPO in comparison with other share issues. This leads us to our fourth hypothesis.

Hypothesis 4. Inventory reductions will be more pronounced after an IPO than after subsequent share issues.

Apart from shares, firms may issue debt to raise capital and they have substantial differences with equity issues that justify a differential impact on inventories. First, equity is a financial instrument with more length than debt. This implies that there is a lower reduction in a firm's liquidity needs after a debt issue. Note that debt has to be renewed with additional issues when expires. Then, in order to prevent future liquidity needs, firms will be less tempted to reduce inventories. Second, lenders generally require some collateral as a counterpart for their provision of capital. This is an intrinsic characteristic of debt contracts, which may hinder inventory reduction as they may be used as tangible collateral (Tribó, 2001). Last, shareholders, as opposed to debtholders, have junior

\footnotetext{
(footnote continued)

previous to the IPO may have some visibility for external investors in their valuation of the company in the absence of more informative signals like stock prices. Once a financially constrained firm is listed, investors rely on stock prices for the valuation of the company and inventories are less informative.

${ }^{6}$ In a different context, Casasola and Tribó (2004) showed that the reduction in the cost of capital is larger after an initial debt issue than after the posterior issues.
}

rights over the cash generated by a project; this is inversely related to the inventories accumulated. Hence shareholders will have more incentives to monitor managers than debtholders and, consequently, avoid the reduction in residual cash as a consequence of mismanagement due to inventory overinvestment. Then, if inventory accumulation is the outcome of a firm's mismanagement, we expect a superior inventory reduction after an equity issue rather than after a debt one. This is our last hypothesis.

Hypothesis 5. Inventory reductions will be larger for share issues compared with debt ones.

\section{Empirical analysis}

\subsection{Data and preliminary evidence}

We carried out our empirical analysis making use of a sample of US firms extracted from COMPUSTAT database for the period 1994-2004. The initial sample had 9079 firms, but we only considered companies for which we had available information of their IPO date. The final sample was an incomplete panel data of 3383 companies that had IPO dates between 1994 and 2004.

To characterize a firm's inventory level, we used the inventory-to-sales ratio on a log scale (Inventory to_Sales). ${ }^{7}$ For the inventory variability we took the standard deviation of the inventory stock year-by-year (SD_Inventory).

Regarding our financing issues variables, we used the following proxies.:

IPO is a dummy variable that was equal to 1 if the year of the observation was posterior to the IPO date and zero otherwise. Equity_Issues is a dummy that was equal to 1 if the equity issued in posterior periods after the IPO had a value larger than then mean value for the sample and zero otherwise. Debt_Issues is a dummy that was equal to 1 if the debt issued by the firm had a value larger than the sample mean value, and zero otherwise. ${ }^{8}$

We approached a firm's financial strength (Financial_ Strength) with the Z-score measure of Bankruptcy (COMPUSTAT mnemonic ZSCORE). ${ }^{9}$ Financial_Strength assumed values of 0,1 , and 2 if the ZSCORE had values lower than 1.8 , between 1.8 and 3 , and larger than 3 , respectively. This corresponds to a high, medium, and low probability of bankruptcy.

The firm size (Size) is the number of employees on a $\log$ scale.

\footnotetext{
${ }^{7}$ The use of a log scale reduces problems of heteroskedasticity in the estimations. However, for the sake of clarity, in Table 1 we have shown the ratio of inventory-to-sales without transforming on a log scale.

${ }^{8}$ The average value of debt and equity issues is a natural benchmark to compare for characterizing those issues that were significant enough.

${ }^{9}$ This concept is a bankruptcy prediction model developed by Altman (1997). If a value less than 1.81 is returned, than there is a high probability of bankruptcy. If a value greater than 3.0 is returned, than there is a low probability of bankruptcy. This item was designed to forecast failure in the short term (up to 2 years).
} 
Table 1

Contingency analysis

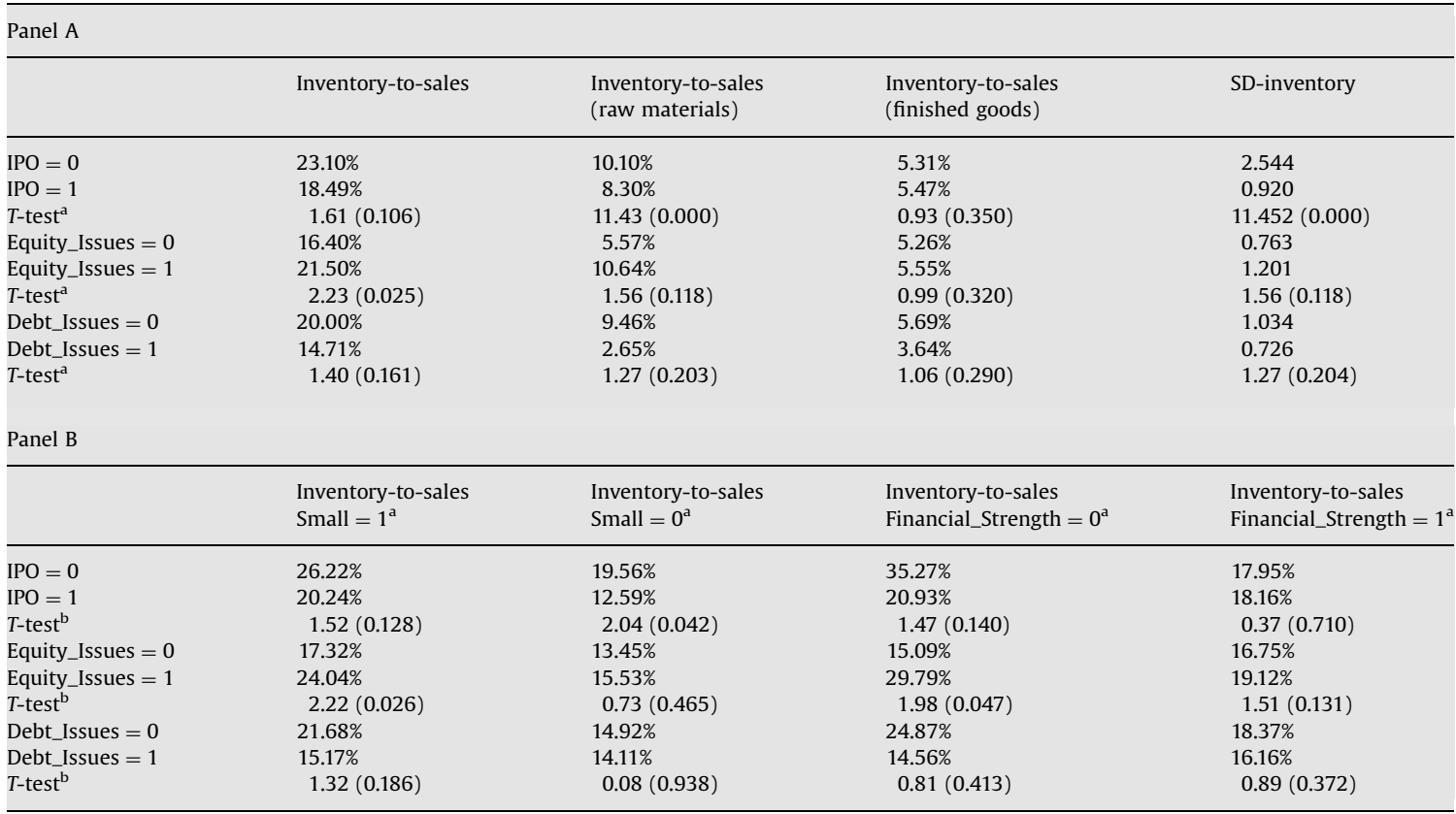

Test of variables that capture variations in the inventory policy contingent on those events that involve debt or equity issues. See the empirical analysis section for the definition of the different variables.

a Small firms means that the variable of employment is lower than the mean value for all the sample (4). Financial_Strength $=1(0)$ means that the $Z$ score measure of Bankruptcy variable (COMPUSTAT mnemonic ZSCORE) has a value larger than 3 (lower than 1.8).

b Test of mean values. P-values are in parentheses.

To contrast Hypothesis 3, we crossed Financial_ Strength and Size with our IPO variable (IPO_Size and IPO_Financial_Strength).

As controls, we introduced a variable of financial structure (Debt_Equity), which was computed as the debt-to-equity ratio. This variable, together with the Financial_Strength measure, are proxies for the firm's liquidity needs. Also, the firm's growth perspectives were approached through the firm's R\&D investment (R\&D). The inclusion of these two variables in the specification was intended to avoid spurious correlations between financial issues measures and those that capture inventory investments. Liquidity needs and growth perspectives may explain both variables, as we have argued in the theoretical part, due to technological shocks. Hence, it was important to control for these two features. Finally, we introduced temporal and sectoral dummy variables.

To provide preliminary evidence of our theoretical contentions, we conducted different tests of mean differences that are displayed in Table 1.

Table 1 shows the variation in inventory level and inventory variability once we compare the periods before and after different significant events: an IPO (row 1), a significant equity issue (row 2), and a significant debt issue (row 3). We found a significant lower inventory-to-sales level in those periods after an IPO.
The percentage decreases from $23.10 \%$ to $18.49 \%$. This conforms to Hypothesis 1. Also, we have found that the reduction after an IPO is more pronounced in rawmaterial inventories rather than for finished-good inventories (columns 2 and 3 of panel A). ${ }^{10}$ This conformed to Hypothesis 2. Concerning the comparison between small and large firms as well as between firms with strong and weak financial strength (panel B), we found that after an IPO, the reduction in inventories was significantly larger in financially constrained firms (Financial_Strength $=0$ ) than for their counterparts. However, we did not detect major differences in terms of the size of firms. This partially conforms to Hypothesis 3. Finally, we did not find evidence of the larger decrease in the inventory level after an equity issue rather than after a debt one.

\subsection{Methods and results}

In this section, we contrast our theoretical contentions relying on regression techniques and taking advantage of the panel data structure of our sample. Our basic

\footnotetext{
${ }^{10}$ In an unreported estimation, we have found that work-in-progress inventories show a variation whose magnitude is larger than that of finished-good inventories but lower than that of raw-material ones.
} 
specification is as follows:

$$
\begin{aligned}
& \text { Inventory_to_Sales }{ }_{\text {it }} \\
& =\beta+\beta_{1} \mathrm{IPO}_{\mathrm{it}}+\beta_{2} \text { Equity_Issues }_{\mathrm{it}} \\
& +\beta_{3} \text { Debt_Issues }_{i t}+\beta_{4} \text { IPO_Size }_{i t} \\
& +\beta_{5} \text { IPO_Financial_Strength }{ }_{\mathrm{it}}+\beta_{6} \text { Size }_{\mathrm{it}} \\
& +\beta_{7} \text { Financial_Strength }_{\mathrm{it}}+\beta_{8} \text { Debt_Equity }_{\mathrm{it}} \\
& +\beta_{9} R \& D_{\mathrm{it}}+u_{\mathrm{i}}+\psi_{\mathrm{t}}+\varepsilon_{\mathrm{it}}
\end{aligned}
$$

where $u_{\mathrm{i}}$ accounts for the unobservable heterogeneity, $\psi_{\mathrm{t}}$ is a temporal error term, and $\varepsilon_{i t}$ is a white-noise error term.

We recognize the possibility that $u_{\mathrm{i}}$ may be correlated with changes in a firm's ownership structure due to equity or debt issues (fixed effects). For example, an intrinsic characteristic of the firm, like the degree of managerial risk aversion, has a clear impact on the probability of an IPO as well as on the type of investment policy that will affect inventory levels. This means that $u_{\mathrm{i}}$ is correlated to the IPO variables as well as IPO_Size and IPO_Financial_ Strength. A second endogeneity problem appears when some independent variables may be correlated with the non-firm specific component of the error term $\varepsilon_{\text {it }}$. It may be the case that an improvement in a firm's technology also increases the efficiency of inventory management (reducing the inventory-to-sales ratio). ${ }^{11}$ At the same time, it may trigger a firm's IPO because of the need of further capital provision to develop this new technology. In this case, the correlation between the IPO variable and the inventory-to-sales would be spurious. In order to eliminate both endogeneity problems, we have conducted a GMM estimation (Arellano and Bond, 1991), where we have taken as instruments of the potential endogenous variables (Equity_Issues and Debt Issues and IPO) the different temporal lags of these variables. However, for the variables IPO, it does not make sense to take temporal lags as instruments, and we have used instead the mean value of these variables for the corresponding sector and year. ${ }^{12}$ The literature reports that IPOs come in waves (Ritter and Welch, 2002) and have a clear sectoral and temporal component. This means that the mean value of the variable IPO will be clearly correlated with IPO. However, these mean values will be uncorrelated with the specific shocks that affect a firm's inventory policy. This makes the variable a good candidate as an instrument. ${ }^{13}$

Table 2 shows four estimations. In column 1 the dependent variable is Inventory_to_Sales. In columns 2 and 3 , the dependent variable is the inventory-to-sales ratio for raw materials and for finished goods, respectively. Finally, in order to test more long-term effect, in column 4 we lead Inventory_to_Sales by one period.

\footnotetext{
11 This kind of shock may explain the great moderation phenomenon of a steady decrease in the output and inventory volatility in the US (Blanchard and Simon (2000); Irvine and Schuh (2004); McConell and Perez-Quiros (2000).

12 For the variables IPO_Size and IPO_Financial_Strength, we have used as an instrument the product of the instrument of IPO times the variables Size and Financial_Strength, respectively.

${ }^{13}$ In all the models of Tables 2 and 3 the null hypothesis of instruments validity is satisfied (Hansen test). Also, there is no secondorder serial correlation in the residuals (AR(2) test).
}

The results of Table 2 confirm that after an IPO, the inventory-to-sales ratio of a firm is lower than in those periods previous to the IPO. ${ }^{14}$ Remarkably, this is also true for more than one period after the IPO. This fully confirms Hypothesis 1 . Once we compare columns 2 and 3, we find that the effect of being listed is more significant for rawmaterial inventories than for finished-good ones. This is in line with Hypothesis 2. Once we focus on the signs of variables IPO_Size and IPO_Financial_Strength, we find that only the latter is significant and positive. This indicates that for firms with financial difficulties, there is a larger reduction in the inventory-to-sales ratio after the IPO. Hence, the liquidity provisions that these firms receive once they are listed on financial markets have superior effects in their inventory policy than their counterparts. However, this differential effect is not appreciable in terms of the Size variable. That is, there is no further reduction in inventory-to-sales ratio after an IPO for small firms when compared with large ones. We can argue that financial constraints affect both small and large firms that decide to go public, in the same way. This confirms Hypothesis 3 partially.

The contrast between Hypothesis 4 and 5 is made by comparing the coefficients of Equity_Issue and Debt-Issue with that of IPO. We find that the IPO coefficient is more negative than that of Equity_Issues. At the same time, the Equity_Issues coefficient is more negative than that of Debt_Issues (which is non-significant). Consistent with Hypotheses 4 and 5, the most significant reductions in inventory-to-sales ratio occur after an IPO, then after a subsequent equity issue and finally after a debt issue.

Concerning control variables, we find that small firms and, marginally, firms with financial difficulties accumulate relatively more inventories. Finally, to investigate the effect of changes in the ownership structure on inventory variability, we estimate the same specification as (1) but using SD_Inventory as a dependent variable. The results are shown in Table 3 and confirm that there is a reduction not only in the inventory-to-sales ratio after an IPO, but also in the inventory variability. Moreover, this reduction is particularly important for those firms with financial difficulties (positive sign of IPO_Financial_Strength). Remarkably, these type of firms as well as small ones show, in general, larger inventory variability, which is consistent with Hendel's (1996) findings and those by Carpenter et al. (1994), who showed that standard deviation of inventory investment is $50 \%$ larger for small than for large firms. Finally, the last column of Table 3 reveals that this effect also holds for more than one period after the IPO.

\section{Conclusions}

This paper shows the influence that being listed in the stock market has on a firm's inventory policy. After an IPO,

\footnotetext{
14 Note that in the system GMM approach, estimations are made in differences. This means that the coefficient of IPO captures the marginal impact on the inventory level once a particular firm changes its regime from non-listed to listed.
} 
Table 2

Estimations on Inventory_to_Sales ${ }^{\mathrm{a}}$

\begin{tabular}{|c|c|c|c|c|}
\hline Dependent variables & Invent-to-sales & Invent-to-sales (raw material) & Invent-to-sales (final goods) & Invent-to-sales $(+1)$ \\
\hline IPO & $\begin{array}{c}-0.480^{* * *} \\
(0.001)\end{array}$ & $\begin{array}{c}-0.450^{* * *} \\
(0.024)\end{array}$ & $\begin{array}{c}-0.330 \\
(0.363)\end{array}$ & $\begin{array}{c}-0.558^{* * *} \\
(0.000)\end{array}$ \\
\hline Debt_Issues & $\begin{array}{r}-0.045 \\
(0.711)\end{array}$ & $\begin{array}{c}-0.175 \\
(0.212)\end{array}$ & $\begin{array}{c}0.248 \\
(0.144)\end{array}$ & $\begin{array}{c}-0.232^{* *} \\
(0.069)\end{array}$ \\
\hline Equity_Issues & $\begin{array}{c}-0.160^{* *} \\
(0.028)\end{array}$ & $\begin{array}{c}-0.211^{* * *} \\
(0.023)\end{array}$ & $\begin{array}{c}-0.324^{* * *} \\
(0.002)\end{array}$ & $\begin{array}{c}-0.171^{* *} \\
(0.033)\end{array}$ \\
\hline IPO_Size & $\begin{array}{c}0.000 \\
(0.883)\end{array}$ & $\begin{array}{c}0.005 \\
(0.319)\end{array}$ & $\begin{array}{c}-0.003 \\
(0.660)\end{array}$ & $\begin{array}{c}0.000 \\
(0.979)\end{array}$ \\
\hline IPO_Financial_Strength & $\begin{array}{c}0.155^{*} \\
(0.107)\end{array}$ & $\begin{array}{c}0.078 \\
(0.554)\end{array}$ & $\begin{array}{c}0.025 \\
(0.919)\end{array}$ & $\begin{array}{c}0.216^{* *} \\
(0.030)\end{array}$ \\
\hline Size & $\begin{array}{c}-0.004^{* * *} \\
(0.001)\end{array}$ & $\begin{array}{c}-0.010^{* *} \\
(0.032)\end{array}$ & $\begin{array}{c}-0.006 \\
(0.334)\end{array}$ & $\begin{array}{c}-0.003^{* * *} \\
(0.003)\end{array}$ \\
\hline Financial_Strength & $\begin{array}{c}-0.148^{*} \\
(0.104)\end{array}$ & $\begin{array}{c}-0.184 \\
(0.132)\end{array}$ & $\begin{array}{c}-0.092 \\
(0.679)\end{array}$ & $\begin{array}{c}-0.155^{*} \\
(0.089)\end{array}$ \\
\hline Debt_Equity & $\begin{array}{c}0.000 \\
(0.881)\end{array}$ & $\begin{array}{c}0.000 \\
(0.972)\end{array}$ & $\begin{array}{c}0.000 \\
(0.576)\end{array}$ & $\begin{array}{c}0.000 \\
(0.841)\end{array}$ \\
\hline R\&D & $\begin{array}{c}0.000 \\
(0.438)\end{array}$ & $\begin{array}{c}0.000 \\
(0.777)\end{array}$ & $\begin{array}{c}0.000^{* * *} \\
(0.001)\end{array}$ & $\begin{array}{c}0.000 \\
(0.414)\end{array}$ \\
\hline Constant & $\begin{array}{c}-2.158^{* * *} \\
(0.000)\end{array}$ & $\begin{array}{c}-2.376^{* * *} \\
(0.000)\end{array}$ & $\begin{array}{c}-2.802^{* * *} \\
(0.000)\end{array}$ & $\begin{array}{c}-1.976^{* * *} \\
(0.000)\end{array}$ \\
\hline Number of observations & 13038 & 7992 & 8129 & 11465 \\
\hline Fitness of the model & $156.69(0.000)$ & $36.50(0.000)$ & $4.96(0.000)$ & $148.69(0.000)$ \\
\hline Hansen test ( $J$ statistic) & $298.43(0.339)$ & $258.30(0.895)$ & $175.87(1.000)$ & $226.00(1.000)$ \\
\hline $\mathrm{AR}(2)$ test & $-1.11(0.267)$ & $-0.27(0.786)$ & $-1.22(0.222)$ & $-1.40(0.162)$ \\
\hline
\end{tabular}

All variables are defined in the empirical section. In column 1, the dependent variable is Inventory_to_Sales, in column 2 it is the raw-material inventoryto-sales, while in column 3 it is the final-good inventory-to-sales. Finally, in column 4, the dependent variable is Inventory_to_Sales led by one period.

${ }^{a} P$-values in parentheses. All specifications include sector and temporal dummy variables * $90 \%$ significant, ${ }^{* *} 95 \%$ significant, ${ }^{* * *} 99 \%$ significant. $F$-test used as fitness test. All are GMM estimations, where we have taken as instruments of the potential endogenous variables, Debt-Issues and Equity_issues the different temporal lags of these variables. For the variable IPO, we have used the mean value of this variable for the corresponding sector and year. For the crossed variables IPO_Size and IPO_Financial_Strength, we have used as an instrument the product of the instrument of IPO times the variables Size, and Financial_Strength, respectively. The $J$ statistic ( $P$-values reported in parentheses) is distributed as chi-squared under the null hypothesis of instruments validity. The $\operatorname{AR}(2)$ is a test for a second-order serial correlation in the residuals which is distributed as $N(0,1)$ under the null hypothesis of no serial correlation.

firms accumulate fewer inventories and reduce their inventory variability not only in the following period, but more than one period ahead. Moreover, we distinguish between raw-material inventories and final-good ones and find that the reduction in inventories after an IPO is more pronounced for the former. Regarding the type of firms, inventory reduction is particularly evident for firms with financial difficulties. We interpret this as evidence suggesting that for these types of firms, the capital raised through the stock market is particularly important and makes inventory accumulation a less relevant tool for sending informative signals on future prospects and marginally so for preventing liquidity shocks.

A second type of results compares the inventory policy when a firm issues debt instead of equity. Notably, the reducing effects on the inventory levels are larger for the equity issue than for debt issue. These results may be explained by the superior provision of current and future liquidity and the larger control of managers that is achieved after an equity issue. Generally, shareholders have larger monitoring incentives to prevent managerial misbehaviour and inventory accumulation because, unlike debtholders, they have junior rights over the cash generated by projects.

We show the above results making use of a database of US manufacturing firms for the period 1994-2004. Remarkably, our results describe a natural stabilizing mechanism that may smooth the economic cycle. In the expansive periods, a significant proportion of firms are listed on the stock market which, according to our results, should generate a decrease in the inventory investment and in the last stage in the production. Conversely, in 
Table 3

Estimations of variation on inventories ${ }^{a}$

\begin{tabular}{|c|c|c|c|}
\hline Dependent variables & SD_Inventory & SD_Inventory & $\begin{array}{l}\text { SD_Inventory } \\
(+1)\end{array}$ \\
\hline IPO & $\begin{array}{c}-7.218^{* * *} \\
(0.003)\end{array}$ & $\begin{array}{c}-7.440^{* * *} \\
(0.001)\end{array}$ & $\begin{array}{c}-1.453^{* *} \\
(0.065)\end{array}$ \\
\hline Debt_Issues & & $\begin{array}{c}-0.665 \\
(0.288)\end{array}$ & $\begin{array}{c}-1.782^{* * *} \\
(0.011)\end{array}$ \\
\hline Equity_Issues & & $\begin{array}{c}0.357 \\
(0.389)\end{array}$ & $\begin{array}{l}0.752^{* *} \\
(0.051)\end{array}$ \\
\hline IPO_Size & $\begin{array}{c}0.037 \\
(0.166)\end{array}$ & $\begin{array}{c}0.041^{* *} \\
(0.060)\end{array}$ & $\begin{array}{c}0.012 \\
(0.345)\end{array}$ \\
\hline IPO_Financial_Strength & $\begin{array}{l}2.470^{* *} \\
(0.074)\end{array}$ & $\begin{array}{l}2.898^{* *} \\
(0.032)\end{array}$ & $\begin{array}{c}0.526 \\
(0.320)\end{array}$ \\
\hline Size & $\begin{array}{c}-0.048^{* *} \\
(0.067)\end{array}$ & $\begin{array}{c}-0.049 \\
(0.122)\end{array}$ & $\begin{array}{c}-0.015 \\
(0.197)\end{array}$ \\
\hline Financial_Strength & $\begin{array}{c}-2.404^{*} \\
(0.075)\end{array}$ & $\begin{array}{c}-2.841^{* *} \\
(0.032)\end{array}$ & $\begin{array}{c}-0.594 \\
(0.221)\end{array}$ \\
\hline Debt_Equity & $\begin{array}{c}0.000 \\
(0.925)\end{array}$ & $\begin{array}{c}0.000 \\
(0.917)\end{array}$ & $\begin{array}{c}0.000 \\
(0.894)\end{array}$ \\
\hline$R \& D$ & $\begin{array}{c}0.000 \\
(0.972)\end{array}$ & $\begin{array}{c}0.000 \\
(0.921)\end{array}$ & $\begin{array}{c}0.000 \\
(0.793)\end{array}$ \\
\hline Constant & $\begin{array}{l}12.606^{* * *} \\
(0.000)\end{array}$ & $\begin{array}{l}12.334^{* * *} \\
(0.000)\end{array}$ & $\begin{array}{l}4.329^{* * *} \\
(0.000)\end{array}$ \\
\hline $\begin{array}{l}\text { Number of } \\
\text { observations }\end{array}$ & 9683 & 9683 & 8998 \\
\hline Fitness of the model & $6.05(0.000)$ & $5.52(0.000)$ & $4.95(0.000)$ \\
\hline Hansen test & $170.23(1.000)$ & $223.42(0.727)$ & $210.80(0.144)$ \\
\hline $\operatorname{AR}(2)$ test & $0.44(0.659)$ & $0.31(0.759)$ & $0.65(0.513)$ \\
\hline
\end{tabular}

All variables are defined in the empirical section. In columns 1, 2 and 3, SD_Inventory (inventory variability) is the dependent variable. In column 4 SD_Inventory is led by one period in order to analyze persistence.

a $P$-values in parentheses. All specifications include sector and temporal dummy variables. ${ }^{*} 90 \%$ significant, ${ }^{* *} 95 \%$ significant, ${ }^{* * *} 99 \%$ significant. F-test used as fitness test. All are GMM estimations, where we have taken as instruments of the potential endogenous variables, Debt-Issues and Equity_Issues the different temporal lags of these variables. For the variable IPO, we have used the mean value of this variable for the corresponding sector and year. For the crossed variables IPO Size and IPO_Financial_Strength, we have used as an instrument the product of the instrument of IPO times the variables Size, and Financial_Strength, respectively. The $J$ statistic ( $P$-values reported in parentheses) is distributed as chi-squared under the null hypothesis of instruments validity. The $\operatorname{AR}(2)$ is a test for a second-order serial correlation in the residuals which is distributed as $N(0,1)$ under the null hypothesis of no serial correlation.

recessive periods, there are a limited number of firms that are sold in financial markets (Ritter and Welch, 2002). This eliminates one of the factors that may generate significant disinvestments which, in turn, may deepen the aggregate contraction in production. Taking a global perspective, along all the economic cycle, the effect described reduces the overinvestment during expansion periods and the underinvestment in recessions. We think the effect that we have described may be relevant, given that that in the US, the proportion of IPOs as a percentage of the overall market value has increased from less than $3 \%$ in 1990 , to a peak of $13 \%$ in 2000 , before the burst of the bubble. After that, the level stabilized around 7\% (Rousseau, 2006). This means that the relative weight of the new firms in the overall economy has increased steadily and that the inventory policies followed by these firms may be a relevant variable to consider in explaining fluctuations in the economic cycle. The investigation of this issue in greater depth is an avenue for future research.

\section{Acknowledgement}

I wish to thank Pascual Berrone and the referees for their helpful suggestions on earlier drafts of this paper. Financial support provided by the project of the Comunidad de Madrid (Grant \# s-0505/tic/000230), from the MEC (Grant \# SEJ2006-09401) and from the Fundación Ramón Areces is gratefully acknowledged. All the errors are my own responsibility.

\section{References}

Altman, R., 1997. Corporate Financial Distress and Bankruptcy. Wiley, New York.

Arellano, M., Bond, S., 1991. Some tests of specification for panel data: Monte Carlo evidence and an application to employment equations. Review of Economic Studies 58, 277-297.

Blanchard, O., Simon, J., 2000. The long and large decline in US output volatility. Brooking Papers on Economic Activity 1 (2001), 135-164.

Blinder, A.S., Maccini, L.J., 1991. Taking stock: A critical assessment of recent research on inventories. Journal of Economic Perspectives 5 (1), 73-96.

Calomiris, C.W., Himmelberg, C.P., Wachtel, P., 1994. Commercial paper, corporate finance, and the business cycle: A microeconomic perspective. Carnegie-Rochester Conference Series on Public Policy 42, 203-250.

Carpenter, R.E., Fazzari, S.M., Petersen, B.C., 1994. Inventory investment, internal-finance fluctuations and the business cycle. Brooking Papers of Economic Activity 2, 75-137.

Casasola, M.J., Tribó, J., 2004. Deuda bancaria y deuda negociable: Un estudio para las empresas manufactureras españolas. Revista Española de Financiación y Contabilidad XXXIII (121), 465-497.

Chen, H., Frank, M.Z., Wu, O.Q., 2005. What actually happened to the inventories of American companies between 1981 and 2000? Management Science 51, 1015-1031.

Gertler, M., Gilchrist, S., 1993. The role of credit market imperfections in the monetary transmission mechanism: Arguments and evidence. Scandinavian Journal of Economics 95 (1), 43-64.

Gomes, A.R., Novaes, W., 2005. Sharing of control as a corporate governance mechanism. PIER Working Paper, 1-12.

Guariglia, A., 2000. Inventory investment and capital market imperfections: A generalization of the linear quadratic inventory model Oxford Bulletin of Economics and Statistics 62, 2.

Hendel, I., 1996. Competition under financial distress. Journal of Industrial Economics 44, 309-324.

Irvine, O., Schuh, S., 2004. The roles of comovement and inventory investment in the reduction of output volatility. Working Paper,Federal Reserve Bank of Boston.

Kashyap, A.K., Lamont, O.A., Stein, J.C., 1994. Credit conditions and the cyclical behavior of inventories. Quarterly Journal of Economics 109 (3), 565-592.

Krautter, J., 1999. Inventory theory: New perspectives for corporate management. International Journal of Production Economics 59 $129-134$.

Lai, R.K., 2005. Inventory and the stock market. Available at SSRN: $\langle$ http://ssrn.com/abstract=789884〉.

Lai, R.K., 2006. Inventory signals. Harvard NOM Research Paper Series No. 05-15. Available at SSRN:〈http://ssrn.com/abstract=723381〉. 
McConell, M., Perez-Quiros, G., 2000. Output fluctuations in the United States: What has changed since the early 1980s? American Economic Review 90 (5), 1464-1476.

Ritter, J., Welch, I., 2002. A review of IPO activity, pricing and allocation. Journal of Finance 57, 215-240.

Rotemberg, J., Saloner, G., 1989. The cyclical behavior of strategic inventories. The Quarterly Journal of Economics 104 (1), 73-97.
Rousseau, P., 2006. General-purpose technologies: Then and now. In: Rhode, P.W., Toniolo, G. (Eds.), The Global Economy in the 1990s. A Long-Run Perspective. Cambridge University Press, Cambridge.

Tribó, J.A., 2001. Inventories, financial structure and market structure. International Journal of Production Economics 71, 79-89.

Tribó, J.A., 2007. Ownership structure and inventory policy. International Journal of Production Economics 108 (1-2), 213-220. 